\title{
EDITORIAL
}

\section{WAR AND SECURITY AT SEA: WARNING SHOTS}

\section{Vincent Bernard, Editor-in-Chief}

Naval warfare and maritime security may seem a surprising theme to choose for the Review today. As a matter of fact, in the last few years most discussion about humanitarian law and action has centred on other spaces such as the arid reaches of Central Asia and the Sahel, urban areas in the Middle East, or even cyberspace, rather than the seas. However, there is a geopolitical chess game under way on the world's oceans, which despite rarely being the centre of media attention, nevertheless carries colossal stakes. The stakes - political, but also environmental and human-are played out on a background of exponential technological developments, of States' assertion of their sovereignty, of globalization of trade and wealth, but also of vulnerability. Our interdependence is laid bare on the ocean waves, for good or ill.

The Review believes that these developments must be understood in terms of the risks they harbour from a humanitarian viewpoint. Naval warfare is changing, and more than 20 years after the Review last dedicated an issue to the subject, ${ }^{1}$ it is time to examine that evolution. In May 2017, the International Committee of the Red Cross (ICRC) published its updated Commentary on Geneva Convention (II) for the Amelioration of the Condition of Wounded, Sick and Shipwrecked Members of Armed Forces at Sea of 12 August 1949 (GC II). This provides an opportunity to reassert the existing legal rules and discuss how to apply them in light of today's realities and the genuine risk of confrontation.

\section{High stakes on the high seas}

A third of the world's oil and a fifth of its gas production takes place at sea, while $90 \%$ of gas reserves lie under the seabed. The oceans contain $84 \%$ of the world's minerals and other raw materials. The world has over 90,000 commercial vessels, ${ }^{2}$ including around 50,000 ships that transport some $90 \%$ of all international freight. ${ }^{3}$ And according to some estimates, $99 \%$ of all transoceanic data traffic goes through undersea cables, including internet usage, phone calls and text 
messages. This route is faster than satellite transmissions. ${ }^{4}$ Economic activity at sea comes in a variety of forms, including passenger transport and cruises; the transport of goods, fuel and raw materials; ports; fishing and aquaculture; offshore oil and gas platforms; marine renewable energies (offshore wind- and wave-power facilities, etc.); and shipbuilding. If the Internet is the symbol of economic globalization, it is the world's ports, container ships and supertankers that make such globalization possible.

If a strategically important seaway were to be disrupted by a conflict - even a relatively limited one - there would be major repercussions on an incalculable number of people who depend directly or indirectly on these economic activities.

As the explorer Sir Walter Raleigh stated in the 1600s, "whosoever commands the sea commands the trade; whosoever commands the trade of the world commands the riches of the world, and consequently the world itself'. ${ }^{5}$ The economic stakes inevitably give rise to power struggles. It is in Asia that present-day disputes about who commands the sea, shipping lanes and the riches beneath the seabed are most acute. ${ }^{6}$

Today, China and a number of other States make competing and diversified claims over large parts of the South China Sea, ${ }^{7}$ across which are transported half of China's trade by volume, but also half of Japan's and South Korea's trade, half of the world's fossil fuels and four fifths of oil tankers coming from the Middle East. ${ }^{8}$

The South China Sea could be the epicentre of a major regional conflict, stoked by renewed nationalism in the region and the need for the various States to ensure economic growth or see their domestic stability collapse. In the last few years, serious tensions have flared in the East China Sea and the Sea of Japan;

1 Thematic issue on "War at Sea", International Review of the Red Cross, Vol. 77, No. 816, 1995.

2 United Nations Conference on Trade and Development, Review of Maritime Transport 2016, UN Doc. UNCTAD/RMT/2016, 7 November 2016, p. 30, available at: http://unctad.org/en/PublicationsLibrary/ rmt2016_en.pdf.

3 Figures quoted in Patrick Hébrard, "Cybersécurité du domaine maritime", Défense et Sécurité Internationale, No. 52, February-March 2017, p. 54. See also: www.statista.com/statistics/264024/ number-of-merchant-ships-worldwide-by-type/ (all internet references were accessed in July 2017).

4 Douglas Main, "Undersea Cables Transport 99 Percent of International Data", Newsweek, 2 April 2015, available at: www.newsweek.com/undersea-cables-transport-99-percent-international-communications319072.

5 Sir Walter Raleigh, "A Discourse of the Invention of Ships, Anchors, Compass, \&c.," The Works of Sir Walter Ralegh, Kt., Vol. 8, 1829 (reprinted 1965), p. 325.

6 The Council on Foreign Relations' Global Conflict Tracker shows that two of the world's five critical conflicts are in the South China and East China seas; see: www.cfr.org/global/global-conflict-tracker/ p32137\#!/. CrisisWatch also has the South China Sea on its radar; see: www.crisisgroup.org/crisiswatch.

7 See, for instance, Barthélémy Courmont and Eric Mottet, "La mer de Chine méridionale: Une mer chinoise?", Diplomatie, No. 84, January-February 2017. For a Chinese perspective see Position Paper of the Government of the People's Republic of China on the Matter of Jurisdiction in the South China Sea Arbitration Initiated by the Republic of the Philippines, Ministry of Foreign Affairs of the People's Republic of China, position paper, 7 December 2014, available at: www.fmprc.gov.cn/mfa_eng/zxxx_ 662805/t1217147.shtml; China Adheres to the Position of Settling Through Negotiation the Relevant Disputes Between China and the Philippines in the South China Sea, Ministry of Foreign Affairs of the People's Republic of China, white paper, 13 July 2016, available at: www.fmprc.gov.cn/mfa_eng/zxxx_ 662805/t138061.

8 Figures quoted in Alexis Bautzmann, "Tensions en mer de Chine”, Diplomatie, No. 84, January-February 2017, p. 3. 
and since 2014, Russia and NATO have once more assumed a Cold War stance in the Baltic Sea and Black Sea. Tensions could flare again in the Persian Gulf, and one could invoke numerous other fault lines between States. Some States are quick to assert their sovereignty, sometimes rejecting the territorial limits set by the law of the sea and drawing their own maritime boundaries. Incidents linked to rival territorial claims could well multiply in the coming years in an isolationist and sovereigntist climate where States appear to be placing more importance on military power than on multilateralism.

In addition to conflict between States seeking control of the seas, there are other security risks below the threshold of armed conflict such as sea-borne terrorism, trafficking of all kinds, and piracy, which still exists in some parts of the world.

$\mathrm{Al}$ Qaeda has claimed responsibility for several attacks at sea, such as those on the USS Cole in 2000, on the French oil tanker Limburg in 2002 and on a passenger ferry in the Philippines in 2004. The terrible attacks in Bombay in November 2008 were also carried out by armed individuals who had travelled to the city undetected by sea. More recently, several vessels have been subjected to rocket or missile attack in the Suez Canal (2013) and in the Gulf of Aden (2016). Coastal holiday resorts have also been targeted in order to disrupt the tourism on which many States rely, particularly African States, which have been severely affected, for example in Kenya (2014), Tunisia (2015) and Côte d'Ivoire (2016). ${ }^{9}$

It is estimated that between 2005 and 2014, piracy off the coast of Somalia cost $\$ 18$ billion in international trade. ${ }^{10}$ Renewed activity by Somali pirates has prompted many States to mobilize naval capabilities, with significant results. Although international naval cooperation has been successful in combating piracy along the Somali coast, piracy (so-called "petro-terrorism") is on the rise in the Gulf of Guinea, in the Philippines and elsewhere. ${ }^{11}$ Time and again, piracy flourishes in lawless coastal areas, places where the government is weak, where corruption is rife, or where there is a failed State. Combating pirates at sea depends on onshore solutions.

The distress suffered by men, women and children taking their chances on makeshift boats recalls scenes of shipwrecks from another era. Many are risking their lives in the uncertain hope of finding refuge, often because they are fleeing even greater danger in the war zones of Iraq, Syria and the Lac region of Chad. Coastguard services are used to combat all kinds of trafficking and for border control, notably to prevent irregular immigration. In the last few years, the most important aim of coastal operations has been to rescue irregular migrants. Certain NGOs have equipped themselves with rescue craft, and the navies of several States are also carrying out rescue missions. Security and humanitarian concerns are closely linked in such

9 Attack in the Suez Canal on the Cosco Asia container ship, 31 August 2013; attacks in the Gulf of Aden on the HSV2 Swift, the USS Mason and the liquified natural gas tanker Galicia Spirit, October 2016; attack in Tunisia on the Riu Imperial Marhaba hotel, 26 June 2015; attack in Grand Bassam, Côte d'Ivoire, 13 March 2016; attack in Lamu, Kenya, 5-6 July 2014.

10 Louis Arthur Borer and Edouard Pfimlin, "La piraterie maritime en Afrique: D'un golfe à l'autre", Défense et Sécurité Internationale, No. 38, October-November 2014, p. 61.

11 International Maritime Organization, Reports on Acts of Piracy and Armed Robbery against Ships: Annual Report 2016, 30 March 2017, available at: www.imo.org/en/OurWork/Security/PiracyArmedRobbery/ Reports/Documents/245\%20Annual\%202016.pdf. 
missions, as are political and identity questions, often set against a background of a public mood of dwindling empathy and the exploitation of xenophobia for political gain.

\section{Naval operations in the twenty-first century}

The world has seen few naval battles since the Second World War, and none have been on a scale similar to those seen in the battles of 1914-18 and 1940-45. ${ }^{12}$ Huge cruisers bristling with large-calibre cannons today lie rusting at the bottom of the ocean.

Indeed, contemporary wars are mainly non-international conflicts, the principal actors of which are always non-State armed groups. Those groups do not have the resources or the strategic interest to obtain naval capabilities, with the notable exception of the Tamil Tigers during the conflict in Sri Lanka. ${ }^{13}$ Conversely, national navies play a sizeable role in, as it were, "high-tech guerrilla operations"-drone strikes, a helping hand for special forces, gathering intelligence, fire support for allied forces, etc. - that States use against armed groups ashore, specifically in counterterrorism operations.

Naval forces, like ground troops, are no longer designed to face up to each other in huge, decisive battles. Their main mission is to monitor and control the three dimensions of the maritime domain - submarine, surface and aerial-and to project air and land force towards the coast when taking part in combined operations; or, when in acting in defence, to prevent such operations from succeeding. Some $80 \%$ of the world's population lives within 200 kilometres of a coastline. Increasingly, therefore, the mission of navies is force projection, including air and amphibious force. A large number of land operations have been conducted entirely or partially from the seas and oceans, recent examples being operations in Afghanistan and Iraq, and air strikes in Syria.

Naval forces are also used to respond to humanitarian crises. For example, Japan and the United States sent ships to help victims of Typhoon Haiyan in the Philippines in November 2013. The US hospital ships USS Mercy and USS Comfort are sent to provide emergency medical care when disaster strikes. ${ }^{14}$

Although they may change in form, naval forces remain an essential part of States' military arsenal. In this way, bases in Crimea and Syria are key components of Russian naval strategy. That strategy cannot be ignored when analyzing the conflicts in these two parts of the world. The navies of Australia, China, Japan and other Far East States are expanding rapidly. Between 2006 and 2016, China

12 The main battles have been the Indo-Pakistani naval war of 1971, the Falklands War between Argentina and the United Kingdom in 1982, and the air-sea battle between the US and Iranian navies around the Sassan and Siri oil platforms in 1988, known to Americans as Operation Praying Mantis.

13 See Malaka Chandradasa, "Learning from Our Enemies: Sri Lankan Naval Special Warfare against the Sea Tigers", CTX Journal, Vol. 2, No. 2, 2012, available at: https://globalecco.org/learning-from-our-enemiessri-lankan-naval-special-warfare-against-the-sea-tigers.

14 See Jesus Diaz, "How the US Navy Uses the Largest Hospital Ships in the World to Help Everyone", Gizmodo, 10 March 2012, available at: https:/gizmodo.com/5948246/how-the-us-navy-uses-the-largesthospital-ships-in-the-world-to-help-everyone. 
nearly doubled the number of modern destroyers and frigates in its fleet. ${ }^{15}$ In April 2017, it launched its first domestically built aircraft carrier. Although naval forces in some Asian States have entered into an arms race, the seas are still dominated by the crushing superiority of the US Navy, which is itself focusing increasingly on Asia.

Deploying naval power allows "gunboat diplomacy" - displays of force intended to show a State's resolve, to intimidate or to assert sovereignty claims. Rival fleets often play dangerous games: naval deployments by NATO and Russia are sometimes accompanied by flyovers and simulated attacks in the Baltic Sea and Black Sea. Fortunately, these instances of "cold" inter-State tension rarely degenerate into open confrontations. Where violence has occurred, it has remained at a low level, quickly contained by diplomatic means to avoid escalation.

Regional organizations can play a major role in managing these rivalries, as in the case of the Association of South East Asian Nations in the South China Sea, as pointed out by Ambassador Ong Keng Yong, the Association's former secretary-general, in the interview that opens this issue of the Review. Even if frequently contested, international justice and arbitration also continue to play an important role in resolving disputes and above all in establishing the rules of the game. ${ }^{16}$

There is an apparent trend in which certain States are adopting an aggressive posture towards others by deploying their naval arsenals in maritime hot spots, increasing the risk of incidents. It must be hoped that States will continue to avoid direct confrontation. However, States will doubtless use other types of limited force that the parties concerned will avoid qualifying as "armed conflict", such as intervention via special forces, "maritime militia", 17 or even merchant ships and fishing vessels. The nature of these operations, which fall short of actual armed conflict, and the laws applicable to them are often intentionally shrouded in fog.

Technology has always played a major role in naval warfare. The times we live in see unprecedented speed in the development of new technologies. Autonomous devices still only distant possibilities in the context of war on land are already being deployed at sea. In 2016 the US Navy launched Sea Hunter, an autonomous ship that can sail not only without a crew but without remote steering. It can patrol the oceans autonomously for seventy days. Once armed, it

15 See Joseph Henrotin, “Mutations de la guerre navale”, Défense et Sécurité Internationale, No. 38, 2014 , p. 8.

16 See, for example, Permanent Court of Arbitration, The South China Sea Arbitration (The Republic of the Philippines v. The People's Republic of China), Case No. 2013-19, Ruling, 12 July 2016. But see also Bill Hayton, "When Good Lawyers Write Bad History: Unreliable Evidence and the South China Sea Territorial Dispute", Ocean Development and International Law, Vol. 48, No. 1, 2017, contesting that arbitration resolved the dispute between the States Parties.

17 See also James Kraska and Michael Monti, “The Law of Naval Warfare and China's Maritime Militia”, International Law Studies, Vol. 91, No. 450, 2015, available at: http://stockton.usnwc.edu/ils/vol91/iss1/ 13/. See also Andrew S. Erickson and Conor M. Kennedy, "China's Maritime Militia: What It Is and How to Deal with It", Foreign Affairs, 23 June 2016, available at: www.foreignaffairs.com/articles/china/ 2016-06-23/chinas-maritime-militia; Andrew S. Erickson and Conor M. Kennedy, "Meet the Chinese Maritime Militia Waging a 'People's War at Sea'", Wall Street Journal Commentary, 31 March 2015, available at: https://blogs.wsj.com/chinarealtime/2015/03/31/meet-the-chinese-maritime-militia-waginga-peoples-war-at-sea/. 
could become the first of a new generation of destroyers. ${ }^{18}$ However, these technologies are extremely expensive and only a small number of States will be able to have access to them.

Cyber-attacks are also a growing threat. Ships and ports are today packed with IT systems that constitute potential targets. If the briny deep is open to one and all, so is cyberspace. Attacks on cyberspace-along with outer space, another "global commons" - could wreak havoc on economic activity, as well as causing shipwrecks and pollution. In a report, the European Agency for Network and Information Security (ENISA) warned of insufficient measures to protect maritime systems, at a time when more than $50 \%$ of goods shipped from Europe are transported by sea. ${ }^{19}$

\section{No such thing as a "clean" war}

Happily, the era of battles between armadas on the high seas seems to be over. In the absence of naval battles, warship crews are no longer being slaughtered. The use of robotics in weapons systems could also reduce military losses in future. However, this does not mean that modern war at sea will be without bloodshed. In our time, distinguishing between civilian and military ships and aircraft remains a problem. Several dozen civilians died recently when a civilian vessel was attacked off the coast of Yemen. The huge stocks of naval mines around the world are every bit as dangerous for civilian ships as they are for naval vessels.

Coastal warfare can have extremely serious consequences for populations. The bombing of ports in Yemen, ${ }^{20}$ combined with the closure of land borders, is now having a devastating effect on Yemen's people, who have always depended on imports for their survival. Cholera has reached epidemic proportions in a population weakened by food shortages, inadequate access to health care and poor hygiene. Blockades are another example of naval tactics that can cause grave humanitarian concern, and States have always made regular use of them, as recent examples in Yemen and Qatar show. The Israeli naval blockade has limited the Gaza Strip's access to the resources it needs for decades, particularly by affecting its fishing industry. ${ }^{21}$

The maritime environment can be contaminated by the effects of hostilities. Radioactive contamination unleashed by, for example, an attack on a nuclear power plant could produce pollution similar to that caused after the Fukushima plant was

18 Phil Stewart, “US Military Christens Self-Driving 'Sea Hunter' Warship”, Reuters, 7 April 2017, available at: www.reuters.com/article/us-usa-military-robot-ship-idUSKCN0X42I4.

19 European Network and Information Security Agency, Analysis of Cyber Security Aspects in the Maritime Sector, report, November 2011, available at: www.enisa.europa.eu/publications/cyber-security-aspects-inthe-maritime-sector-1/at_download/fullReport.

20 See, for example, Stephen Snyder, “The Threat of War over Yemen's main Seaport Is Slowing Delivery of Food Aid”, Public Radio International, 29 April 2017, available at: www.pri.org/stories/2017-04-29/ if-theres-war-around-port-its-going-have-grave-consequences.

21 See Ezz Zanoun, "Work at Sea: The Daily Struggle of Gaza's Fishermen", photogallery, ICRC, 15 December 2016, available at: www.icrc.org/en/document/photo-gallery-gaza-fishermen\%23photo-32596. 
damaged by a natural catastrophe. Attacks on nuclear-powered ships pose the same risk. During the "Tanker War" between 1984 and 1988, several hundred oil tankers were attacked in the Persian Gulf as part of the Iran-Iraq War. And seas could be intentionally polluted in order to harm coastal populations.

Reference was made above to the situation of people who are risking their lives by taking to the seas in order to seek refuge or a better life abroad. This major source of humanitarian concern will be addressed in a forthcoming issue of the Review dedicated to displacement.

\section{A reality check for the law}

The sea is an open space where both rivalry and the need for cooperation between nations crystallize. As such, it has shown itself to be a key area for the development of norms of international law. For example, the ban on piracy is an ancient rule of the sea. Very early on in the development of international law, pirates were defined as hostis humani generis (enemies of mankind), and any State that captured them had the authority to try them, in what was the first example of universal jurisdiction.

For decades, judgments on maritime cases by the International Court of Justice (ICJ) have defined the broad principles of international law, some examples being the Corfu Channel, ${ }^{22}$ North Sea Continental Shelf ${ }^{23}$ and Nicaragua ${ }^{24}$ cases.

Various bodies of law are relevant when considering violence at sea, and should be interpreted as complementary: the law of the sea (the most important source of which is the United Nations Convention on the Law of the Sea $(\mathrm{UNCLOS})^{25}$ ), international humanitarian law (IHL), human rights law, the law of neutrality and environmental law.

The broad principles of IHL, which mainly concern the protection of noncombatants, are identical regardless of where the fighting occurs - land, sea, air, outer space or cyberspace. The cardinal principle of protection in war at sea is the belligerents' obligation to take all possible measures to help the shipwrecked, regardless of who they are. ${ }^{26}$ During war at sea, surviving sailors not only become hors de combat if their ship sinks: if not rescued, they are condemned to a slow, horrific death. The obligation to come to their aid has been universally accepted for centuries. ${ }^{27}$

The duty to render assistance to shipwrecked people also applies in peacetime $^{28}$ and has been particularly important in recent years given the number

22 ICJ, Corfu Channel Case, Judgment, 9 April 1949, ICJ Reports 1949, p. 4.

23 ICJ, North Sea Continental Shelf Case, Judgment, ICJ Reports 1969, p. 3.

24 ICJ, Military and Paramilitary Activities in and against Nicaragua (Nicaragua v. United States of America), Merits, Judgment, ICJ Reports 1986, p. 14.

25 United Nations Convention on the Law of the Sea, 1833 UNTS 3, 10 December 1982 (entered into force 16 November 1994).

26 GC II, Art. 18; GC IV, Art. 16.

27 Emer de Vattel, The Law of Nations or the Principles of Natural Law Applied to the Conduct and to the Affairs of Nations and of Sovereigns, Vol. 1, London, 1758, p. 170.

28 For example, Article 98 of UNCLOS. 
of people risking their lives in the Mediterranean to seek asylum or migrate to Europe.

Until the First World War, armed conflicts at sea were mainly governed by the Hague Conventions of 1907 and customary law. Developments in the two World Wars raised the question of whether the balance established by IHL at sea between military necessity and humanitarian needs was still being respected. For example, means and methods of war such as submarines, naval mines, long-range missiles and, increasingly, aviation led to numerous attacks against neutral, civilian and hospital ships. ${ }^{29}$

The safety of civilians, the use of blockades and the creation of maritime exclusion zones have continued to raise questions, for example during the Falklands War, the Iran-Iraq War and the 1991 Gulf War. A group of experts and government representatives worked on non-binding directives between 1987 and 1994. These are set out in the San Remo Manual on International Law Applicable to Armed Conflicts at Sea (San Remo Manual), ${ }^{30}$ adopted in 1994. The San Remo Manual is, for the most part, still a valid restatement of customary and treaty international law applicable to armed conflicts at sea. ${ }^{31}$

GC II deals with the protection of injured, sick or shipwrecked members of the armed forces. In May 2017, the ICRC published its updated Commentary on GC II, ${ }^{32}$ which brings up to date the legal interpretations of various provisions of the Convention. There have been changes in both practice and law since the initial 1960 Commentary, particularly with the adoption of UNCLOS and other treaties adopted under the auspices of the International Maritime Organization. ${ }^{33}$ Military capabilities have also grown, particularly in terms of increasing strike range, which has profoundly transformed the nature of war. New technologies such as satellite imaging mean that vessels in distress and shipwrecked survivors can be located more effectively. Locating bodies after a shipwreck is also being made easier by the use of underwater robots. The updated Commentary takes these developments into account.

However, there remain several grey areas and questions arising from recent developments. For example, should the concept of the use of force at sea be defined more clearly, given practices adopted by States? Since there is a fine line between "incidents at sea" and "armed conflict", how best to distinguish mere "incidents" from actual international conflict, for which the definition threshold is low under IHL? How best to cover the activities of underwater robots and autonomous

29 See Louise Doswald-Beck, "The San Remo Manual on International Law Applicable to Armed Conflicts at Sea”, International Review of the Red Cross, Vol. 77, No. 816, 1995, pp. 635-647.

30 Louise Doswald-Beck (ed.), San Remo Manual on International Law Applicable to Armed Conflicts at Sea, Cambridge University Press, Cambridge, 1995.

31 It has been argued, however, that it may be time to consider updating parts of the San Remo Manual. See, in particular, Wolff Heintschel von Heinegg, "How to Update the San Remo Manual on International Law Applicable to Armed Conflicts at Sea", Israel Yearbook on Human Rights, Vol. 36, 2006.

32 See ICRC, "Updated Commentary Brings Fresh Insights on Continued Relevance of Geneva Conventions for Warfare at Sea", 4 May 2017, available at: www.icrc.org/en/document/updated-commentaries-secondgeneva-convention.

33 See the International Maritime Organization website, available at: www.imo.org/EN/Pages/Default.aspx. 
ships? Do they have passage rights under UNCLOS? Should they be qualified as warships and thus entitled to engage in attacks?

\section{Addressing the humanitarian consequences}

Even if it remains quite exceptional, humanitarian actors can carry out rescue at sea operations. For instance, at time of writing, Médecins Sans Frontières is using three ships, in partnership with SOS Méditerranée, to rescue migrants in the Mediterranean. ${ }^{34}$

Furthermore, just as modern naval operations aim above all to project power onto land, the use of ships by humanitarian organizations enables rapid deployment of medical materials and evacuation of people when crises occur in coastal regions. In recent years, the ICRC has used ships to evacuate injured people, ${ }^{35}$ return detainees safely to their homes and reunite people separated from their loved ones. ${ }^{36}$ It has also used them to transport relief supplies, most recently in Yemen. ${ }^{37}$

Humanitarian organizations face the same difficulties gaining access to combat zones at sea or by sea as they do on land. On this note, one humanitarian in charge of evacuating injured people during the war in Sri Lanka explained:

Bringing a boat into a conflict area is a delicate undertaking which we will become involved in only if both sides provide us with the necessary assurances. They do this because they recognize the neutral and independent nature of our work. Only when the safety of our staff, passengers and the vessel itself have been guaranteed can an evacuation by sea take place. ${ }^{38}$

Speaking at the launch of the updated Commentary on GC II, ICRC president Peter Maurer stated that the ICRC is thinking about procuring hospital ships in order " $[\mathrm{t}] \mathrm{o}$ adapt to the complex reality of modern-day warfare and the growing challenges of assisting victims of armed conflicts". He noted that "[s]uch vessels would significantly increase the ICRC's emergency response capacities and would allow us to innovate and adapt to a rapidly changing world". ${ }^{39}$

Another area where international actors could do more is in training and prevention of violations of IHL. The ICRC's military training experts are concerned that the rules of IHL-also known as the law of armed conflict (LOAC) - applicable to maritime operations are relatively poorly understood and little taught by many navies. In addition, there are currently very few people

34 See Médecins Sans Frontières, "10 Things You Need to Know about the Mediterranean Crisis”, 2 December 2016, available at: www.msf.org/en/article/10-things-you-need-know-about-mediterranean-crisis.

35 In Sri Lanka in 2009; see Morven Murchison, "Sri Lanka: Organizing Medical Evacuations by Sea", interview, ICRC, 26 February 2009, available at: www.icrc.org/eng/resources/documents/interview/srilanka-interview-260209.htm.

36 In Libya in 2011; see ICRC, "Libya: Reuniting Hundreds of Families", press release, 23 June 2011, available at: www.icrc.org/eng/resources/documents/news-release/2011/libya-news-2011-06-23.htm.

37 In 2015; see ICRC, "Red Cross and Red Crescent Relief Aid in Yemen", 28 September 2015, available at: www.icrc.org/en/document/red-crossred-crescent-relief-efforts-yemen.

38 M. Murchison, above note 35.

39 The text of his remarks can be found in this issue of the Review. 
specializing in these matters. In recent years, the ICRC has organized specialist workshops ${ }^{40}$ to increase knowledge about the LOAC, particularly in Asia. The "LOAC at Sea for Naval Operators" workshop is now in its fourth year, and further events are planned for 2017: the "LOAC at Sea for Military Lawyers" workshop and the "Maritime Security Course for Police and Security Forces". The International Institute of Humanitarian Law in Sanremo also organizes regular workshops on naval operations and the law. ${ }^{41}$ This edition of the Review is intended to help generate fresh interest in issues of humanitarian concern and the resulting rules applicable to war and security at sea.

\section{A shot across the bows}

In their "techno-thriller" Ghost Fleet, Peter W. Singer and August Cole envisage a third World War which takes place mainly at sea, with the use of futuristic technologies. ${ }^{42}$ The two authors are not science-fiction novelists but experts renowned for their cutting-edge analysis of conflicts. The weapons systems they describe either already exist in certain arsenals or reflect current military trends.

At the moment, we are witnessing the adoption of a tougher stance by States in many areas of tension across the world's seas. These growing tensions, combined with rapid growth in naval power and States' aggressive deployment to disputed areas, is exacerbating the risk of incidents and even open hostilities around kinetic flashpoints. The Persian Gulf, the Baltic Sea or the South China Sea could be the scene of the twenty-first century's first major regional conflict. Due to globalization, a conflict in one of these interdependent maritime spaces would inevitably have repercussions on the economies of multiple nations and on the lives of countless people, both near and far. In addition to these risks, there are many other situations involving the use of force at sea: trafficking, terror attacks and, as always, piracy, which show no signs of stopping.

Faced with these threats, humanitarian actors have little experience and few means to respond at sea. Meanwhile, the protagonists of war at sea do not have a sufficient knowledge of the applicable rules. Of course, even more so than on land, the speed of technical and strategic change in maritime operations necessitates continuous reflection on how to ensure that the law keeps pace with a shifting reality. However, none of the current evolutions in tactics or technologies challenges the relevance of the general principles of IHL at sea. It is first and foremost the duty of naval tacticians, engineers and fighters to learn and apply the existing law. They may need its protection again soon.

40 See, for example ICRC, "Indonesia: Naval Officers Discuss Law of War at Sea", 21 November 2016, available at: www.icrc.org/en/document/indonesia-naval-law-war-sea-maritime.

41 See International Institute of Humanitarian Law, "Naval Operations and the Law", available at: www.iihl. org/naval-operations-and-the-law/.

42 Peter W. Singer and August Cole, Ghost Fleet: A Novel of the Next World War, Mariner Books, Boston, MA, and New York, 2015. 